\title{
ANALIZA CRIMEN \\ AMBITUS W ŚWIETLE \\ HISZPAŃSKICH LEGES \\ MUNICIPALES/COLONIARUM \\ I WCZEŚNIEJSZYCH \\ REGULACJI PRAWNYCH
}

\author{
Emilia Twarowska-Antczak ${ }^{1}$ \\ https://doi.org/10.18778/8220-421-6.16
}

\begin{abstract}
In this work, I focus on issues concerning the responsibility of city officials for crimen de ambitu in the light of Spanish leges municipales/ coloniarum and earlier legislation. In a system created by the ancient Romans, responsibility was intended to safeguard the interests of municipalities in the event of management irregularities. Therefore, the applicant for the office of duumvir or quaestor was obliged to set a cash security - cautio. One of the key problems of the Roman republic, and later the Roman municipia (also during the principate) was the corruption of voters with the aim of getting them to cast a ballot for a particular candidate. During the principate era, electoral crime was mainly committed outside Rome, which is why I analyse the legal norms contained in Spanish city laws in the context of Republican legislation.
\end{abstract}

Keywords: leges municipales/coloniarum, legal acts, leges de ambitu, official, public law, responsible officials.

1 Uniwersytet im. Adama Mickiewicza; emilia.twarowska@gmail.com 
Słowa kluczowe: leges municipales/coloniarum, akty prawne, leges de ambitu, urzędnik miejski, prawo publiczne, odpowiedzialność urzędnika.

\section{1. \\ Stowo wstępne}

Studia nad prawem municypalnym antycznego Rzymu są ciągle aktualne i służą do szukania podobieństw, a nawet wykazania ciągłości kulturowej w zakresie organizacji autonomii lokalnych (Sitek, 2008: 13).

Z tego też względu badanie takich zagadnień jak wykonywanie prac publicznych, kwalifikacje kandydatów na urzędy publiczne, urzędnicy pomocniczy, przeciwdziałanie korupcji, jak i wymiar sprawiedliwości posiadają walory poznawcze nie tylko dla romanistów, ale także dla szerokiego grona badaczy antyku, jak i jego miłośników (ibidem). Ponadto zauważalne stopniowe wzmacnianie pozycji lokalnych społeczności jest istotnym elementem polityki Unii Europejskiej. Istnieje trend promowania zaangażowania obywateli w proces decyzyjny w sprawach dotyczących ich małej społeczności - ich miejscowości (Albertini, 1923; Sitek, 2011: 255). Tym samym odwołujemy się do tradycji dobrze nam znanej z okresu istnienia Imperium Rzymskiego, kiedy to małe społeczności - kolonie, municypia - były podstawą „uformowania się jednego, zwartego i sprawnego organizmu państwowego" (Twarowska-Antczak, 2018: XVIII). Istotne podobieństwa organizacji municypiów istniejących w Imperium Rzymskim i współczesnych samorządów gminnych zachęcają do przeprowadzenia badań prawno-porównawczych. W pracy tej skupię się na zagadnieniach odpowiedzialności urzędników miejskich za crimen de ambitu / crimen ambitus w świetle hiszpańskich leges municipales/coloniarum oraz wcześniejszych regulacji prawnych. 


\section{2.}

\section{Crimen ambitus w świetle regulacji republikańskich}

Jedną z najważniejszych pożądliwości człowieka jest chęć zdobycia i posiadania władzy. To właśnie ta pożądliwość od najdawniejszych czasów sprawia, że kandydaci na urzędy dopuszczają się różnych oszustw wyborczych. Tak też było w republikańskim Rzymie. Stąd też dość wcześnie pojawiły się regulacje prawne, których celem było zwalczenie nadużyć wyborczych (crimen ambitus) (Sitek, 2010: 5).

Pomimo zmiany ustroju na pryncypat, za czym podążyło stopniowe przejmowanie przez cesarzy prawa do nominowania na najwyższe funkcje w państwie, przestępczość wyborcza nie została wyeliminowana. Nadal bowiem stosowano republikański system wyboru urzędników w prowincjach i municypiach, obsadzano bowiem stanowiska w administracji lokalnej, przy pomocy zgromadzeń ludowych. Tym samym miały one charakter zgromadzeń wyborczych (Wołodkiewicz, 2007: 124). Z tego też względu jednym z największych problemów rzymskiej republiki (Sobczyk, 2014: 11), później zaś rzymskich municypiów (także podczas pryncypatu) było korumpowanie wyborców w celu skłonienia ich do głosowania na określonego kandydata. Za pryncypatu przestępczość wyborcza w główniej mierze występowała poza Rzymem, o czym wspomina Modestyn - jurysta z III wieku po Chr.:

Haec lex in urbe hodie cessat, quia ad curam principis magistratuum creatio pertinet, non ad populi favorem. Quod si in municipio contra hanc legem magistratum aut sacerdotium quis petierit, per senatus consultum centum aureis cum infamia punitur. Qua lege damnatus si alium convicerit, in integrum restituitur, non tamen pecuniam recipit. (D. $48,14,1$ ) 
Modestyn zauważa, że lex Iulia de ambitu (szerzej o tej ustawie poniżej) nie była już stosowana w Rzymie, miała ona jednak zastosowanie w miastach prowincjonalnych, tj. municypiach i koloniach. Fakt ten zapewne przedłużył jej żywotność, obowiązywała ona bowiem jeszcze w czasach Justyniana, choć znaczenie miała tylko w wyborach w municypiach i koloniach (C. 9, 26, 1; Wołodkiewicz, 2007: 124; Sobczyk, 2014: 22). W celu zrozumienia i omówienia odpowiedzialności urzędniczej za przestępstwa wyborcze w municypiach w okresie pryncypatu należy sięgnąć do źródeł, a dokładniej - wprowadzanych regulacji prawnych oraz znanych z przekazu źródłowego procesów w tym zakresie.

Próba metod zmiany wyniku wyborów była bardzo zróżnicowana: darowizny pieniędzy i przysług dla wyborców, presja i zastraszanie w czasie głosowania, stronniczość i korupcja sędziów odpowiedzialnych za liczenie głosów i ogłaszanie zwycięzcy. Jednak tej próbie nieprawidłowości cały czas przeciwstawiały się inicjatywy mające na celu zapewnienie prawidłowego przebiegu wyborów. Wpływanie na wolę wyborców związane jest zarówno z samym aktem oddania głosu, jak i uniemożliwieniem wzięcia udziału w wyborach (Wołodkiewicz, 2007: 120). Nacisk na wyborców może także polegać na zmasowanej propagandzie, mającej swe odbicie w różnego rodzaju realnych i nierealnych obietnicach; oraz wpływu na wolę wyborców poprzez płacenie za oddanie głosu, bądź też poczęstunek lub innego rodzaju przysłowiową „,kiełbasę wyborczą” (ibidem). Podstawowym źródłem do niniejszych zagadnień są przede wszystkim leges de ambitu (ustawy przeciw przestępstwom wyborczym), ale również leges sumptuariae (ustawy przeciwko zbytkowi) (Twarowska-Antczak, 2019: 119-129) oraz leges tabellariae (ustawy regulujące głosowanie). Skupmy się na leges de ambitu, których nazwa pochodzi od lacińskiego słowa ambio, -ire, -ivi, -itum, co oznacza w pierwszym znaczeniu „obchodzić”, „objeżdżać”, „krążyć”, „opływać”, ale również „obchodzić miasto”, czy też „udawać się do znajomych celem pozyskania ich głosów przy wyborach"2 2 Na tej podstawie

2 ambio, ire, ii, itum, w: Słownik łacińsko-polski (2007): tom I A-C. Warszawa: 2007: 168; ambitus, w: Słownik łacińsko-polski (2007): 
wnioskuje się, że ambitus oznaczał pierwotnie „obchodzenie miasta przez kandydatów podczas i przed wyborami w celu zbierania głosów" aby z biegiem czasu przyjąć znaczenie na prawne i bezprawne sposoby zdobywania głosów (Zandberg, 2001: 104). Należy jednak podkreślić, że termin ten najczęściej jest stosowany w znaczeniu pejoratywnym (Appel, 2019: 213). Bardzo trudno uzyskać satysfakcjonującą jego definicję, co ma swoją przyczynę w źródłach, które koncentrują się na karach stosowanych przy ambitus, nie zaś na istocie tego terminu (Schuller, 2000: 352; Appel, 2019: 213-214).

Podstawowymi przestępstwami wyborczymi, określanymi mianem ambitus, były: largitio (przekupienie wyborców), crimen sodaliciorum (udział w stowarzyszeniach zajmujących się organizacją przestępstw wyborczych) oraz coitio (koalicje wyborcze w celu wyeliminowania trzeciego kandydata). Najwięcej rozbieżności interpretacyjnych wśród badaczy przysparza coitio ${ }^{3}$. Powszechnie bowiem uważane było za koalicję wyborczą, która miała doprowadzić do wyeliminowania trzeciego kandydata w grze o funkcję konsula. Przedstawiciele szkoły klasycznej tj. Th. Mommsen (1843: 55-56), L.R. Tayllor (1968: 64, 68) wskazywali jakoby coitio było jednym z przestępstw publicznych - wchodzących w skład ambitus. Ten punkt widzenia podważali, nadając legalność coitio U. Hall (1964: 302), za nim zaś E.S. Staveley (1972: 205) i E.A. Bauerle (Bauerle, 1990: 96 i nn) narzucając nową lekcję Scholia Bobiensis ${ }^{4}$. Współcześni

tom I A-C. Warszawa: 169; Mokrobiusz (Saturnalia I 14,5) twierdzi, że ma on tożsame znaczenie z circumire; Sextus Pompeius Festus (ambitus, w: De verborum signigficatu) podaje dwa znaczenia: pas ziemi między budynkami umożliwiający przechodzenie („proprie dicitur circuitus aedificiorum patens in latitudinem pedes duos et semissem, in longitudinem idem quod aedificium...”) oraz przestępstwo z żądzy pieniędzy lub sprzecznego z prawem ubiegania się o zaszczyty („....sed et eodem vocabulo crimen avaritiae vel affectati honoris appelllatur").

3 coitio, onis, w: Pieńkos, 1996: Warszawa: 80.

4 "M. Licinius Crassus (...) pertulitu, ut severissime quaereretur in eos candidates, qui sodales sibi comciliassent, ut per illos pecuniam 
badacze dystansują się od jednoznacznej klasyfikacji coitio. Badania A. Zandberga jednoznacznie wskazują na niemożność klasyfikacji niniejszej czynności jako przestępstwa bądź też nie (Zandberg, 2001: 104-105).

Pomimo, że leges de ambitu powstały już w okresie wczesnej republiki, zdecydowana ich większość została uchwalona w okresie jej końca. Za T. Walling przyjmuje podział leges de ambitu na trzy grupy: pierwsza z nich to okres 432-314; drugi to 181-159; trzeci zaś to ustawy z I wieku (Wallinga, 1994: 411). Ustawy te wprowadzały różnego rodzaju sankcje, tj. wygnanie z miasta, wykluczenie z życia politycznego dożywotnio lub na 10 lat, kary pieniężne itp. Wiedzę o treści leges de ambitu posiadamy nie z samych ustaw, bowiem nie zachowały się one nawet fragmentarycznie. Wspominają o nich głównie źródła literackie, zwłaszcza dzieło Tytusa Liwiusza ${ }^{5}$ i dzieła Marka Tulliusza Cycerona ${ }^{6}$, jak i sporadycznie prawnicze 7 . Fakt ten spowodował, że ustalenia dotyczące datacji, treści regulacji, oraz podmiotów zaangażowanych w ich powstanie niejednokrotnie pozostają w nauce sporne, często oparte na hipotezach (Sobczyk, 2014: 12). Zaś współcześni badacze - romaniści - nazywają je, jak podaje M. Sobczyk, przekupstwem wyborczym (Kowalski, 1983: 107 i n.; Kowalski, 1987/1988: 7 i n.; Wąsik, 2012: 23 i n.; Sobczyk, 2014: 12), korupcją wyborczą lub przedwyborczą (Wołodkiewicz, 2007: 120 i n.; Lintott, 1990: 1 i n.; Montgomery, 2011: 165; Sobczyk, 2014: 12), nadużyciem wyborczym (Sitek, 2010: 5; Sobczyk, 2014: 12), intrygą wyborczą (Frỳdyk, 2010: 57-60; Sobczyk, 2014: 12), niedozwolonymi praktykami zmierzającymi do przekonania do oddania głosu na właściwego kandydata (Kołodko, 2012: 68; Sobczyk, 2014: 12).

tribulibus dispertirent ac sibi mutuo eadem suffragationis emptae praesidia communicarent". Tłum.: M. Lucjusz Krasuss postanowił, aby najostrzej traktować tych kandydatów, którzy zjednywali sobie członków stowarzyszeń, by przy ich pomocy rozdzielać pieniądze wewnątrz tribus, wspólnie korzystając w tym głosowaniu z nabytej pomocy". Według lekcji Mommsena zamiast sodales było alios.

5 Szczegółowe odwołania w aneksach.

6 Szczegółowe odwołania w aneksach.

7 Rzymscy juryści nawiązują do owych ustaw wyjątkowo rzadko. 
Przestępstwa regulowane ustawami de ambitu rozstrzygane były przez quaestori perpetua de ambitu. Istnieje pewne prawdopodobieństwo, że powołanie takiego trybunału powstało w drodze lex Cornelia Fluvia de ambitu z 159 r. przed Chr. (Fascione, 1984: 55 i n.). M. Sobczyk obala tę teorię w swojej pracy poświęconej lex de ambitu, wskazując jednocześnie na drugą połowę II w. przed Chr. jako bardziej prawdopodobny, (Sobczyk, 2014: 22; Sobczyk twierdzi tak za: Bauerle, 1990: 45 i n.; Robinson, 1995: 84; Nadig, 1997: 29; Kołodko, 2012: 94 i n.) oraz na 116 r. przed Chr. jako rok pierwszego znanego najstarszego procesu przed taką quaestio (Sobczyk, 2014: 22, przyp. 98).

W materiale źródłowym odnajdujemy informację o 41 procesach de ambitu, połowa z nich (22) dotyczyła wyborów konsula, 8 zaś wyborów pretora. Nie oznacza to wcale mniejszego stopnia korupcji przy staraniach o niższe funkcje urzędnicze rzymskiej republiki. Może to być natomiast spowodowane mniejszym zainteresowaniem antycznych pisarzy, w tym historiografów. Nic tak bowiem nie ekscytuje jak najwyższa władza, która niewątpliwie mieściła się w funkcjach konsularnych ${ }^{8}$.

Liczba procesów wzrastała systematycznie w związku z gwałtownym zaostrzeniem walki wyborczej, czemu sprzyjało wszelkiego rodzaju działanie, celem osiągniecia stanowiska. W I wieku przed Chr. korupcja wyborcza osiągnęła swoje apogeum, przejawiało się to nawet w gwałtownym, często dwukrotnym, wzroście oprocentowania udzielanych podczas kampanii pożyczek pieniężnych. Trudno jednoznacznie założyć jakie sumy przeznaczano na korumpowanie wyborców. Zdaniem M. Sobczyka mogły one sięgać nawet 10000000 sestercji, i to tylko podczas jednej kampanii ${ }^{9}$. Taka sytuacja niejednokrotnie prowadziła do bankructwa kandydata przegranego (Cic. Att. 4, 15, 7; Sobczyk, 2014: 24). Znane są też przypadki skazania obu wybranych kandydatów na funkcję konsula (Asc. 75; Scholia Bobiensis 78-79;

8 Sobczyk (2014: 25) wskazuje, że najlepiej udokumentowane są te procesy w które zaangażowany był sam autor ich przekazu źródłowego - Cyceron.

9 idem (2014: 24) w swoich badaniach podąża za Bauerle, 1990: 21. 
Sobczyk, 2014: 24), lub też oskarżenie całej czwórki kandydatów w procesie de ambitu (Cic. Att. 4, 18, 3; 4, 17,5; Cic. Ad Quin. frat. 3, 2, 3; 3, 3, 3. Linderski, 1966: 145 i n.; Nadig, 1997: 111, 123 i n.; Sobczyk, 2014: 24).

W stan oskarżenia stawiani byli zarówno wygrani, jak i przegrani kandydaci na dany urząd, z tą różnicą, że ci pierwsi w zdecydowanej większości. Motywy, którymi kierowali się oskarżyciele, jak twierdzi M. Sobczyk, były bardzo osobiste, tj. chęć wyeliminowania przeciwników politycznych, bądź też chęć odzyskania poprzedniego statusu, wtedy gdy oskarżyciel był osobą uprzednio skazaną za ambitus (Sobczyk, 2014: 26). Należy podkreślić, że proces taki mógł się odbyć w każdym momencie, za wyjątkiem kandydatów którzy wygrali. Dla tych drugich musiało to nastąpić przed wstąpieniem na urząd albo po jego zakończeniu, ze względu na przysługujący urzędnikowi immunitet. Zgodnie z przekazem źródłowym 18 z nich zakończyło się skazaniem, a 19 uniewinnieniem. Wypada podkreślić, że wyroki uniewinniające nie dają pewności co do bezpodstawnego oskarżenia. Udowodnienie przestępstwa nie było łatwe. Należy bowiem zdać sobie sprawę z trudu materiału dowodowego, zwłaszcza gdy kandydat - później oskarżony, posługiwał się osobami trzecimi - divisores czy też sodales do korumpowania wyborców. Ponadto w korumpowaniu wyborców często pomagały rodzina, przyjaciele oraz inni jego polityczni protektorzy. W zwyczaju było, że to co zabronione było w stosunku do kandydata, wykonywali jego poplecznicy, tym sposobem obchodzono np. zakaz organizacji igrzysk. Ponadto, M. Sobczyk wskazuje, że do danych tych nie można podchodzić bezkrytycznie, gdyż równie palącym problemem w tych czasach było korumpowanie nie tylko oskarżycieli, ale i samych sędziów (Sobczyk, 2014: 26, szczególnie przypis 129). Co więcej, oskarżyciele, jak i potencjalni sędziowie - czyli wyborcy należący do wyższych sfer, byli często beneficjentami korupcji wyborczej, dlatego też nie leżało w ich interesie jej zwalczanie (ibidem: 26-27). Nie da się jednak nie zauważyć, że w żadnym $\mathrm{z}$ procesów w stan oskarżenia nie zostali postawieni Juliusz Cezar, Gnejusz Pompejusz i Marek Krassus. Źródła bowiem wskazują, że pierwszy z nich przeznaczył ogromną sumę 
na cele korupcyjne podczas kampanii na urząd pontifex maximus, a mimo to nie został oskarżony de ambitu (Suet. Div. Iuli. 13; Sobczyk, 2014: 27-28). Pompejusz również nie poniósł odpowiedzialności karnej, pomimo, że dopuścił się korumpowania wyborców, w celu osiągnięcia konsulatu w roku 60 przed Chr. przez jego protegowanego Luciusza Afraniusza (Cic. ad Attic. 1, 16, 12; Plut. Pomp. 44, 3-4; Sobczyk, 2014: 27-28). Należy zgodzić się z Sobczykiem, że „brak procesów względem nich można jednak wytłumaczyć tym, że byli tak potężni, że nikt nie odważył się ich oskarżać” (Sobczyk, 2014: 28).

\section{3. \\ Crimen ambitus w świetle leges municipales/coloniarum}

Leges municipales/coloniarum dają możliwość wglądu w regulację prawną dotyczącą odpowiedzialności urzędniczej, w tym też odpowiedzialności za crimen de ambitu. Wszystkie z zachowanych praw pochodzą z Półwyspu Iberyjskiego, z okresu dynastii flawijskiej. Należy jednak nadmienić, że nie są one jedynym zachowanym źródłem regulującym funkcjonowanie municypiów rzymskich. Na półwyspie Appenińskim zachowały się lex Tarentina oraz lex Heracleensis z Heraklei, na półwyspie Iberyjskim zaś lex Iulia Genetiva Ursonensis z Urso (Osuna, Sewilla). Leges municipales, datowane na czasy Domicjana, zamykają proces municypalizacji Hiszpanii rozpoczęty przez Wespazjana (Twarowska-Antczak, 2012: 173-174). Z zachowanych leges municipales tylko w ośmiu przypadkach jesteśmy w stanie zlokalizować ich proweniencję. Koncentrują się ona głównie wokół niewielkich ośrodków miejskich, tj. Salpensa, Irni, Villona, Italica, Corticata, Ostippo, Iliturgicola oraz Carruca, za wyjątkiem Lex Malacitana - Malaca. Biorąc pod uwagę podział administracyjny Półwyspu Iberyjskiego, ukonstytuowany w czasach Augusta, widzimy, że miasta te położone są na terenie dwóch z trzech prowincji, na które dzieliła się Hispania, mianowicie Betyki oraz Hiszpanii Bliższej. Zaznaczyć należy, że wyłącznie jeden fragment pochodzi 
z tej ostatniej, żaden zaś z zachowanych fragmentów nie pochodzi ani ze stolicy prowincji (Corduba i Tarragona), ani ze stolicy okręgów sądowniczych (conventus iuridici). Najwięcej zaś pochodzi z conventus Hispalensis cztery; z conventus Astigitanus trzy oraz z conventus Gaditanus tylko jedno (Twarowska-Antczak, 2012: 173-174). Ustawy te nie powstały w próżni. Wyrosły one z wcześniej istniejących regulacji republikańskich. Niejednokrotnie nawiązując do nich, a nawet kopiując rozwiązania prawne.

Niestety, nie posiadamy pewnych informacji o sądownictwie karnym w municypiach i koloniach rzymskich. Idąc za W. Litewskim można wskazać na duumwirów iure dicundo, jako na organ mający w swojej władzy system sądownictwa - wskazując jednocześnie istnienie sądów lokalnych. Pierwsze znane nam źródło regulujące niniejsze kwestie to lex Iulia municipalis ${ }^{10}$. Zgodnie z nimi to właśnie sądy lokalne rozstrzygały sprawy karne na czele z duumviri iure dicundo. W. Litewski podkreśla, że istnieje brak dowodów aby mówić, iż sądownict wo karne należało do iuridici (Litewski, 2003: 67).

Przepisy antykorupcyjne w rzymskich ustawach miejskich tyczą się kilku podmiotów. Po pierwsze kandydata na urząd, po drugie osoby, której kandydatura nie została jeszcze oficjalnie zgłoszona oraz osób trzecich, które same nie były kandydatami i nie miały w zamiarze ubiegać się o urząd ale czyniły to w imieniu kandydata - lobbując na jego korzyśćl11. Regulacja ta nie jest novum, ponieważ ustawodawstwo rzymskie znało już podobne rozwiązania.

10 Więcej na temat lex Iulia municipalis patrz: Twarowska-Antczak, 2018.

11 LU 132 „ne quis in c(olonia) G(enetiua) post h(anc) l(egem) datam petitor kandidatus,/ quicumque in c(olonia) G(enetiua) I(ulia) mag(istratum) petet, magistratus\{ue\} peten-/ di causa in eo anno, quo quisque anno petitor/ kandidatus mag(istratum) petet petiturusue erit, mag(istratus) pe-/tendi $\langle\mathrm{c}$ (ausa) $\rangle$ conuiuia facito neue at cenam quem\{ue\}/ uocato neue conuiuium habeto neue facito $\mathrm{sc}($ iens $)<\mathrm{d}(\mathrm{olo})>\mathrm{m}(\mathrm{alo}), /$ quo qui $<\mathrm{s}>$ suae petitionis causa conui<ui $>$ um habeat/ ad cenamue quem\{ue $\}$ uocet, praeterdum quod ip-/se kandidatus petitor in eo anno, <quo $>$ mag(istratum) petat,/ uocari[t] dumtaxat in dies sing(ulos) $\mathrm{h}$ (omines) (nouem) conui<ui $>$ um/ hab $<$ uerit $>$, si uolet, s(ine) $\mathrm{d}($ olo) $\mathrm{m}($ alo). neue 
Zakaz, którym zostały obłożone powyższe podmioty dotyczył organizacji uczt lub biesiad (convivium) ${ }^{12}$ oraz obiadów (cena) ${ }^{13}$ dla większej liczby osób niż 9 w przeciągu jednego dnia. Zjawisko organizacji tego typu spotkań w celu pozyskania przychylności

quis petitor kandidatus/ donum munus aliudue quit det largiatur peti-/tionis causa sc(iens) $\mathrm{d}(\mathrm{olo}) \mathrm{m}(\mathrm{alo})$. neue quis alterius petitionis/ causa conuiuia facito neue quem ad cenam uoca-/ to neue conuiuium habeto, neue quis alterius pe-/titionis causa cui quit $\mathrm{d}$ [on]um munus aliutue quit/ dato donato largito sc(iens) $\mathrm{d}(\mathrm{olo}$ ) $\mathrm{m}$ (alo). si quis atuersus ea/ fecerit, (sestertium) (quinque milia) c(olonis) c(oloniae) G(enetiuae) I(uliae) d(are) d(amnas) e(sto), eiusque pecuniae cui eor(um)/ uolet rec(iperatorio) iudic(io) aput IIuir(um) praef(ectum) $<$ ue $>$ actio petitio per-/sec(utio)que ex h(ac) l(ege) i(us) potest(as)que esto”. Tłum.: „Niech nikt w colonia Genetiva Iulia po wydaniu tej ustawy, będąc kandydatem lub ubiegając się o jakiś urząd w colonia Genetiva Iulia, z powodu ubiegania się o urząd w tym roku, lub powzięcia zamiaru ubiegania się o urząd, nie organizuje żadnych przyjęć, nie zaprasza na obiad, ani niech świadomie i podstępnie nie wystawia, ani nie organizuje przyjęć w celach wyborczych, z wyjątkiem sytuacji, gdy kandydat ubiegający się w danym roku o urząd, zaprosi kogoś na ucztę bez posądzenia o podstępne działanie, byleby w ciągu jednego dnia nie przyjął na uczcie więcej niż 9 osób. Ponadto niech żaden kandydat $z$ powodu ubiegania się o urząd nie daje, hojnie obdarowuje podarkiem, prezentem albo czymś innym pod zarzutem podstępnego działania. Niech nikt z powodu ubiegania się o urząd przez kogoś inne gonie organizuje bankietu, nie zaprasza nikogo na biesiadę, nie wydaje uczty ani niech nikt z powodu ubiegania się o urząd przez kogoś innego nie rozdaje w jego imieniu prezentów, hojnie nie obdarowuje podarkiem, prezentem lub czymś innym pod zarzutem podstępnego działania. Jeśli ktoś uczyni coś przeciwko temu, niech będzie ukarany karą grzywny w wysokości 5000 sestercji na rzecz mieszkańców colonia Genetiva Iulia. Każdy obywatel na podstawie tej ustawy niech ma prawo i uprawnienie do wystąpienia ze skargą, pozwem i roszczeniem o tę sumę do trybunału rekuperatorów za pośrednictwem duumwirów lub prefekta wobec duumwirów”. Sitek, 2008: 82-83.

12 Convivium czyli biesiadowanie polegające na organizacji uczty w domostwie lub na wolnym powietrzu o dowolnej porze dnia stwarzała możliwości zaproszenia dużej liczby gości.

13 Cena, czyli główny posiłek dnia podawany zazwyczaj około 15. 
przyszłych wyborców było już spotykane w okresie republiki. Z tego też powodu stopniowo wprowadzano ograniczenia drogą ustaw de ambitu. Niemożliwe było wprowadzenie całkowitego zakazu. Należy bowiem pamiętać, że ucztowanie w starożytnym Rzymie oraz na terenie municypiów/kolonii było przejawem gościnności wynikającej z istniejących stosunków społecznych panujących w tamtym okresie. $Z$ tego też powodu takie ograniczenia B. Sitek interpretuje jako przejaw racjonalności ustawodawcy (Sitek, 2008: 84), bowiem w ten sposób ograniczano możliwość wykorzystania elementów życia codziennego dla celów politycznych, nie ingerując jednocześnie w życie rodzinne. Pośrednio zapewne wpływ na niniejsze ograniczenia miały leges sumptuariae, czyli ustawy przeciw zbytkom, a w szczególności leges cibariae (ustawy o wydatkach). Z szeregu ustaw, które były wydane najbliższa czasom lex Ursonensis jest lex Antia. Została ona uchwalona prawdopodobnie między 70 a 66 r. przed Chr. przez trybuna ludowego Gajusza Antiusza Restora. Ustawa ta przede wszystkim zakazywała przyjmowania zaproszeń na uczty osobom pełniącym urząd oraz tym, które o urząd się ubiegały - designatus. Tym samym takie działanie traktowano jako niedozwoloną praktykę wyborczą (ambitus) (Sitek, 2010: 5-15; Kołodko, 2012: 67-103; Rominkiewicz, 2016: 4). B. Sitek przypuszcza, że regulacje prawne z lex Antia wpłynęły na wprowadzenie analogicznych rozwiązań do lex Ursonensis (Sitek, 2010: 9). Należy jednak pamiętać, że lex Antia to prawdopodobnie lex imperfecta, tzn. nieobjęta sankcją. Prawdopodobnie było to powodem, że niestety, nie spotkała się z przychylnością wśród współczesnych. Nie była ona również skuteczna w przeciwdziałaniu korupcji podczas piastowania urzędów (Jurewicz, 2012: 40). W związku z tym Makrobiusz przekazał nam pewną anegdotę, jakoby jej twórca, widząc, że ustawa jest łamana, postanowił do końca swego życia spożywać posiłki w domu. Dopiero Lex Ursonensis wprowadza sankcję grzywny w wysokości 5000 sestercji na rzecz mieszkańców kolonii/ municypium za każde naruszenie prawa.

Zakaz antykorupcyjny nie ograniczał się tylko do zakazu organizacji biesiad, zakazywał również rozdawania prezentów lub podarków (donum munus) w celu pozyskania sympatii 
wyborców. Prawdopodobnie ustawodawca pod pojęciem prezent/ podarek rozumiał zarówno podarki posiadające wartość majątkową jak i obowiązek publiczny - czyli obietnicy wyborczej, że po wygranych wyborach zwolni z określonych obowiązków publicznych tych, którzy na niego głosowali (Sitek, 2010: 10). Ponadto zakazywano także innych form przekupstwa - świadomego lub podstępnego (Perelli, 1994: 71 i n.; Sitek, 2008: 84). Pierwowzory niniejszej regulacji znajdowały się w republikańskich leges de ambitu. B. Sitek, za: L. Fascione, przyjmuje jakoby już w lex Cornelia Fulvia de ambitu (159 r. przed Chr.) znajdowały się regulacje skierowane przeciwko praktykom prowadzonym przez divisores (osoby, które podczas kampanii wyborczej dystrybuowały pieniądze przeznaczane na korumpowanie). Bardziej prawdopodobne, choć także przysparzające dużo wątpliwości jest uznanie Lex Calpurnia de ambitu - 67 r. przed Chr. (Asconius 69C, Scholia Bobiensia 78-79 St; Cass. Dio 36, 38, 2-5; Linderski, 1966: 116; Kowalski, 1983: 113 i n.; Kowalski, 1987/1988: 11, Lintott, 1990: 7; Nadig, 1997: 107; Mommsen, 1899: 870; Zandberg, 2001: 111; Sobczyk, 2014: 15-16) jako pierwszej regulującej kwestię działalności divisores ${ }^{14}$. Wydaje się, że normy prawne zawarte w lex Ursonensis są powieleniem, bądź były inspirowane regulacjami z lex Licinia de sodaliciis (Pro Planc. 45-47). Była ona skierowana przeciwko stowarzyszeniom sodalicia lub sodalitates. Organizacje te były bardzo wygodną formą dystrybucji pieniędzy „,z ukrycia” (miało to zapobiec oskarżeniu kandydata o ambitus). W trakcie kampanii wyborczej organizowali oni dystrybucję podarków i przysług za poparcie na rzecz określonego kandydata; zastraszali także wyborców kontrkandydatów (Fascione, 1984: 109 i n.; Kowalski, 1987/1988: 12; Bauele, 1990: 75 i n.; Lintott, 1990: 9; Nadig, 1997: 60; Montgomery, 2011: 31 i n.; Wąsik, 2012: 25 i n.; Sobczyk,

14 Jest to sporna kwestia wśród badaczy. Zgodnie z tradycyjną szkołą taki projekt miał być dopiero wprowadzony w lex Tullia de ambitu (Mommsen, 1899: 870). Powołując się na Askoniusza (ASC. 66) alternatywne pole widzenia zaprezentowali Linderski (1966 116), a także Fascione (1984: 67). Zdaniem zaś Zandberga (2001: 111-112) i Sobczyka (2014: 15-16) kwestia ta zostaje nadal nierozstrzygnięta. 
2014: 18-19). Tym sposobem odróżniano crimen ambitus oraz crimen sodaliciorum; proces de ambitu nie wykluczał jednocześnie procesu de sodaliciis w odniesieniu do czynów popełnionych podczas tej samej kampanii wyborczej ${ }^{15}$. Działanie niezgodnie z niniejszymi przepisami wiązało się z karą grzywny w wysokości 5000 sestercji na rzecz mieszkańców kolonii/municypium za każde naruszenie prawa. Dochodzono tego w drodze skargi popularnej, tzn. mogącej być złożoną przez każdego obywatela niniejszego miasta. Prawdopodobnie regulacja ta dokonana była na podstawie inspiracji wcześniejsza lex Aufidia. Według jej zapisów kandydat jest zobowiązany zapłacić 3000 sestercji na rzecz przekupionego już wyborcy (Zandberg, 2001: 119). Należy jednak podkreślić, że odpowiedzialności karnej podlegał tylko korumpujący - sprawca korupcji, nie zaś skorumpowany - przyjmujący korzyść majątkową w formie podarków.

\section{4. \\ Podsumowanie}

Doświadczenie prawa rzymskiego stanowi dowód na to, że skuteczne zwalczanie korupcji wyborczej napotyka bardzo duże trudności. Mimo rozbudowanej legislacji i surowej sankcji karnej trudno twierdzić, że ustawodawca rzymski odniósł sukces na tym polu (Sobczyk, 2014: 29).

Korupcja istniała w świecie rzymskim i była zjawiskiem powszechnym, ale jednocześnie zjawiskiem potępionym jako zaburzenie równowagi społecznej. Był to jednak system mocno powiązany z „typem państwa”, w którym władza była w rękach

15 Na temat zależności miedzy nimi patrz: Fascione, 1984: 109; za przykład może posłużyć oskarżenie w dwóch niezależnych procesach zarówno o ambitus, jak i o crimen sodaliciorum T. Annius Milo (w 52 r. przed Chr.) oraz M. Valeriuss Mesalla Rufus (w 51 r. przed Chr.): Cic. Ad Atticum 11,22, 2 i Asconius 39 C i 54 C. 
elit, one zaś opierały swoją supremację na kryterium pochodzenia. Regulacje prawne dotyczące crimen de ambitu miały na celu ograniczenie owego procederu, który swoim zasięgiem przekroczył granice Urbs. Dotarł do najodleglejszych stron Imperium, co widoczne jest $\mathrm{w}$ regulacjach leges municipales/coloniarum z Półwyspu Iberyjskiego. $Z$ tego też względu nawiązywanie lub czerpanie z regulacji republikańskich było naturalną koniecznością. Na podstawie przeprowadzonych badań należy wskazać szczególnie dwie regulacje republikańskie lex Aufidia oraz lex Licinia de sodalicis, które służyły jako wzór dla regulacji owej kwestii w leges municipales/coloniarum. 


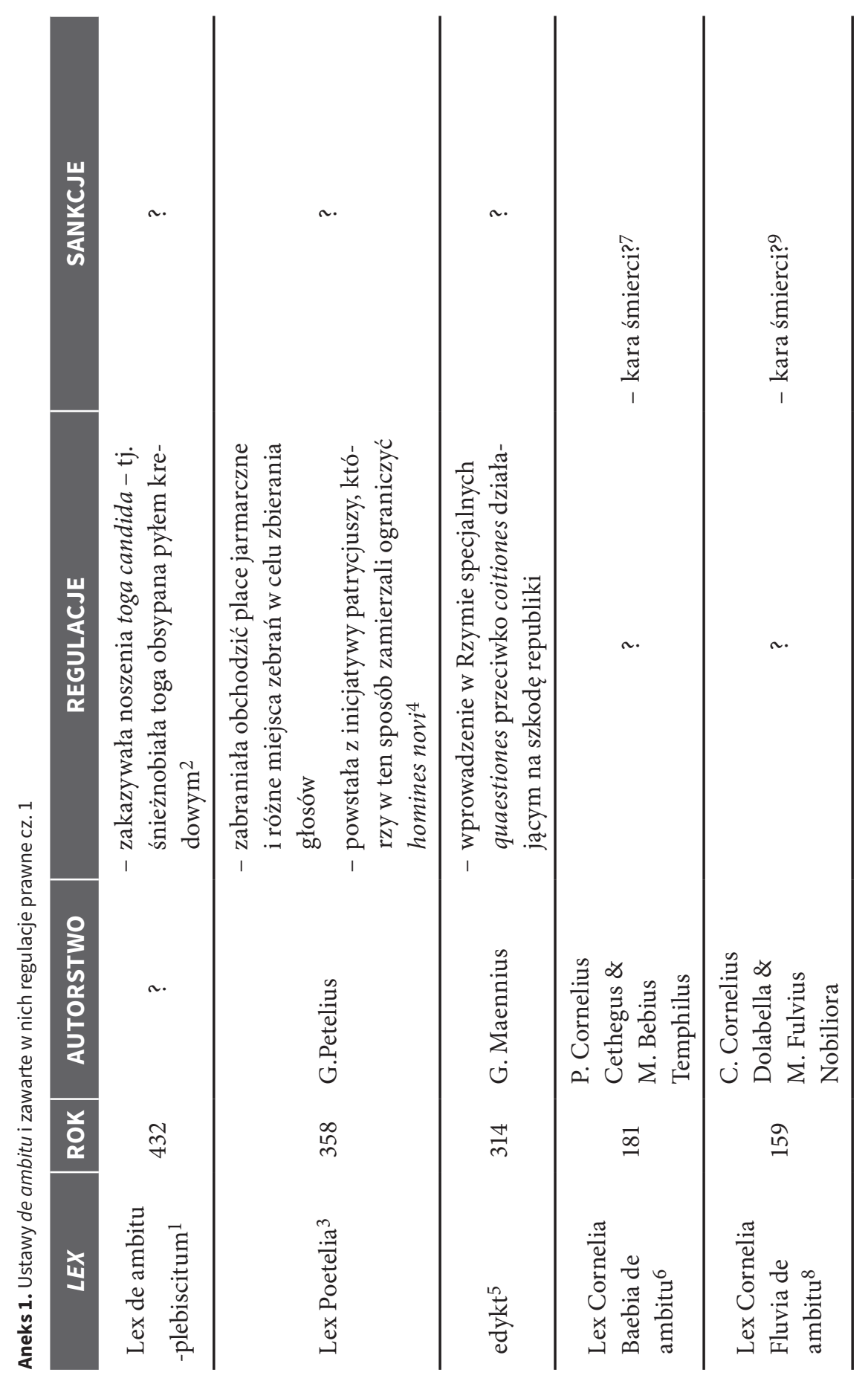




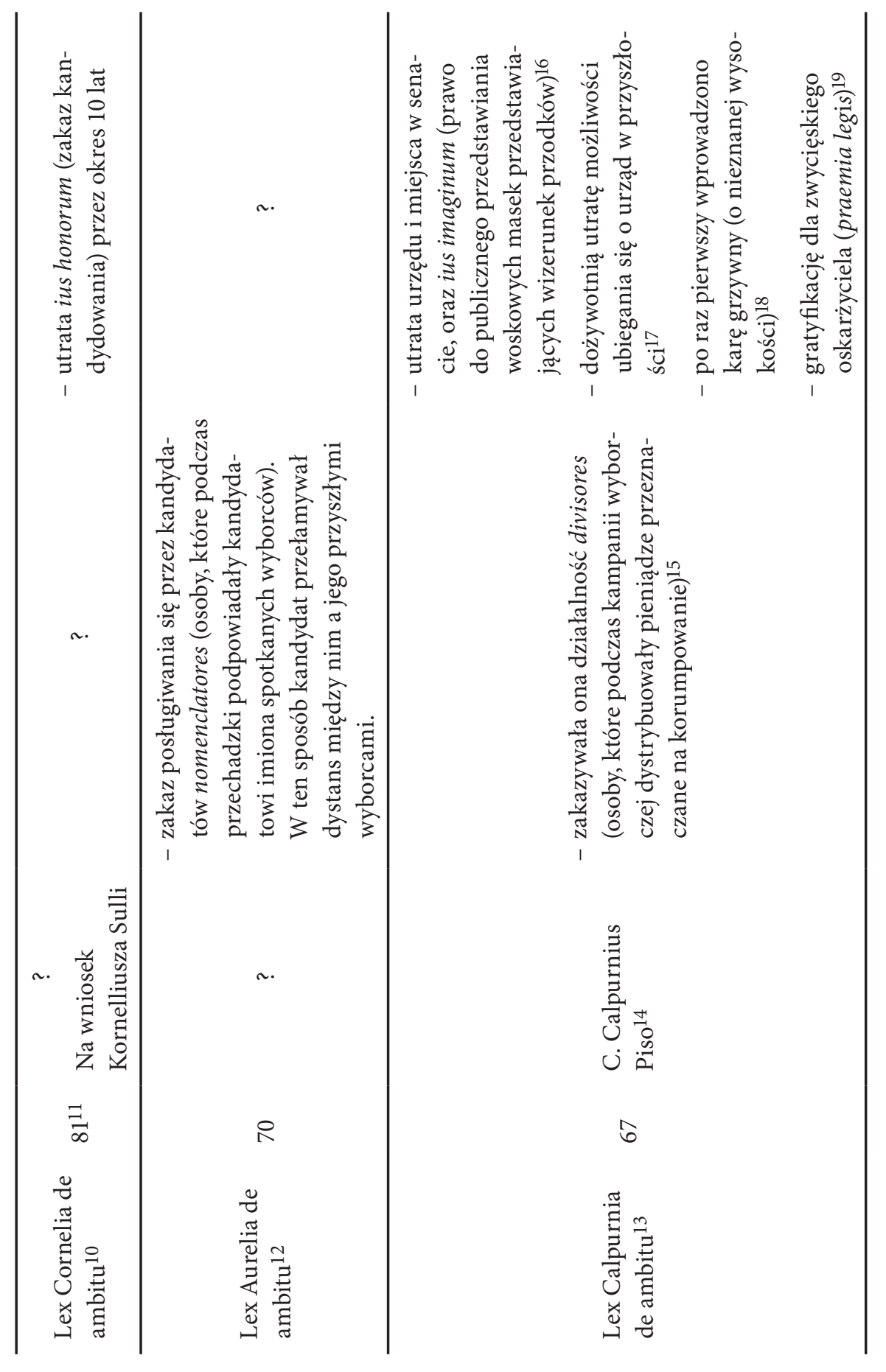




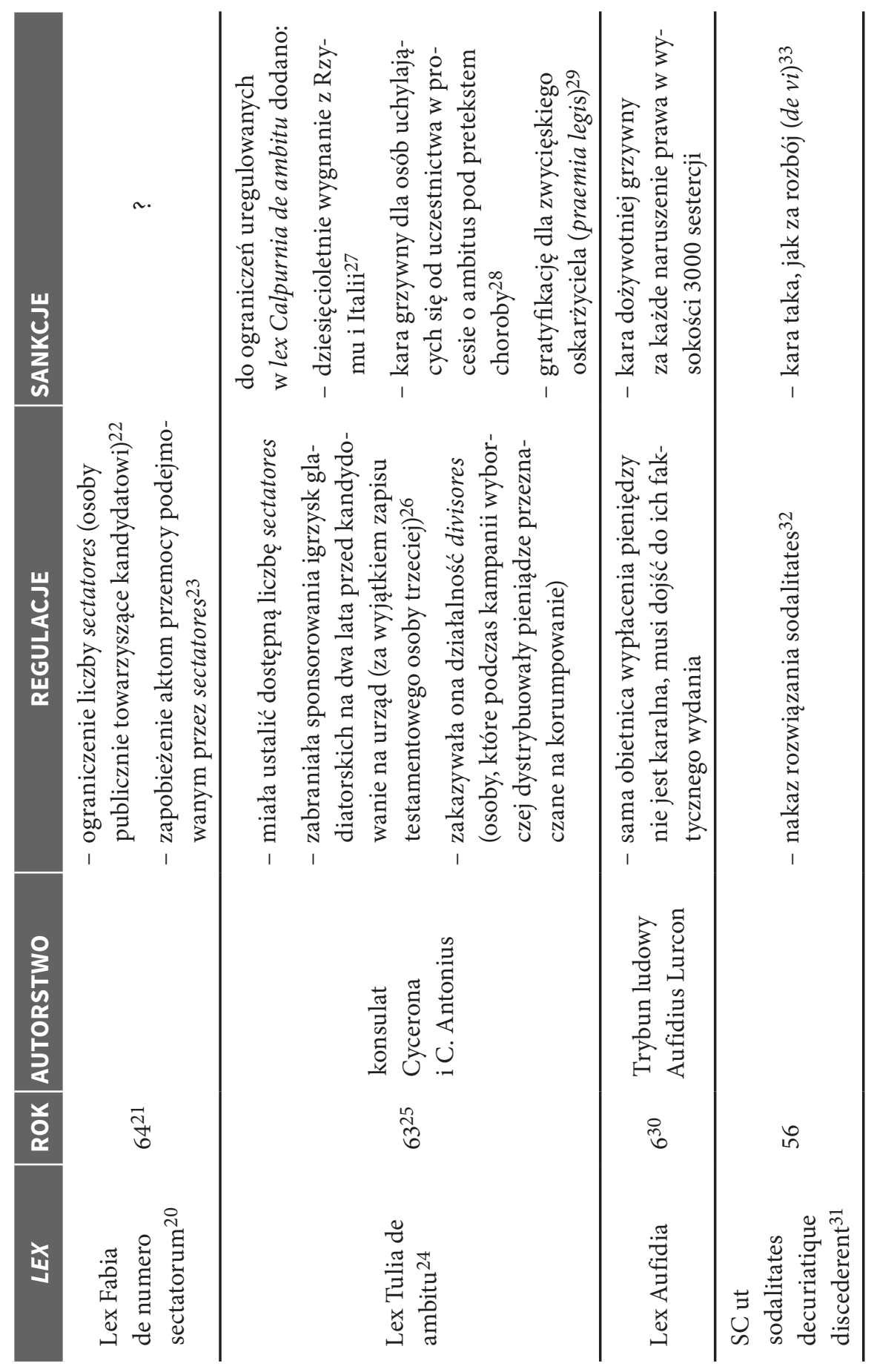




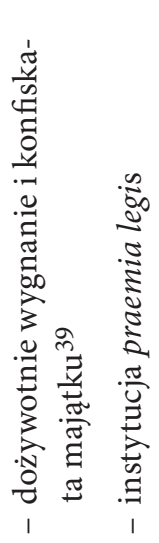

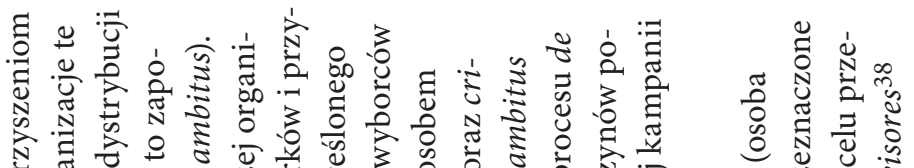

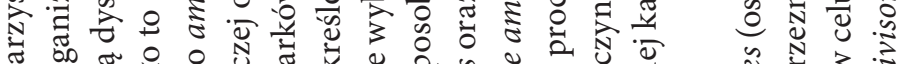

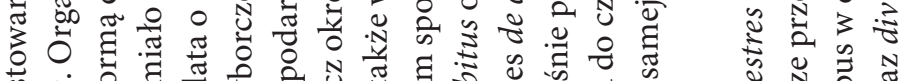

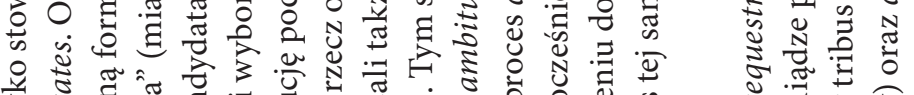

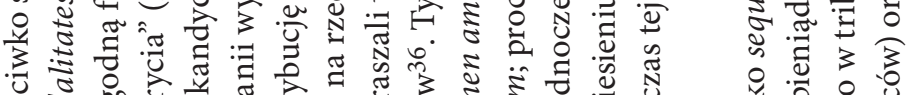

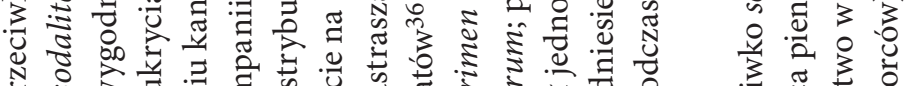

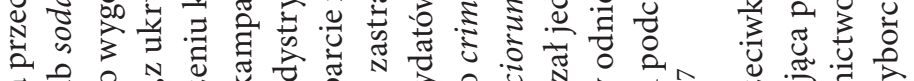

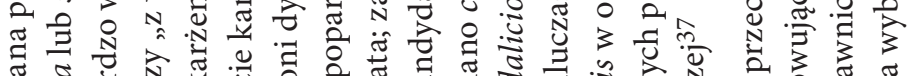

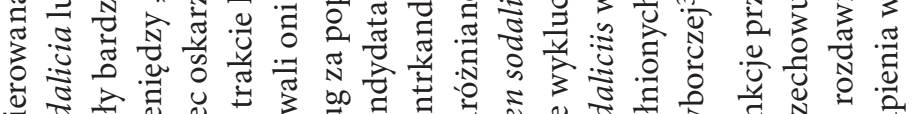

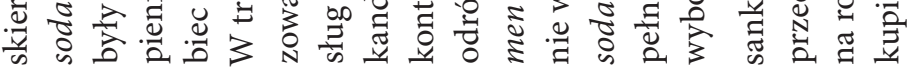
।

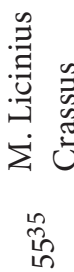

胥

‡

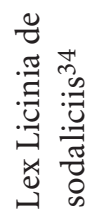

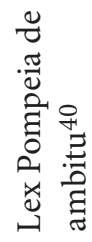




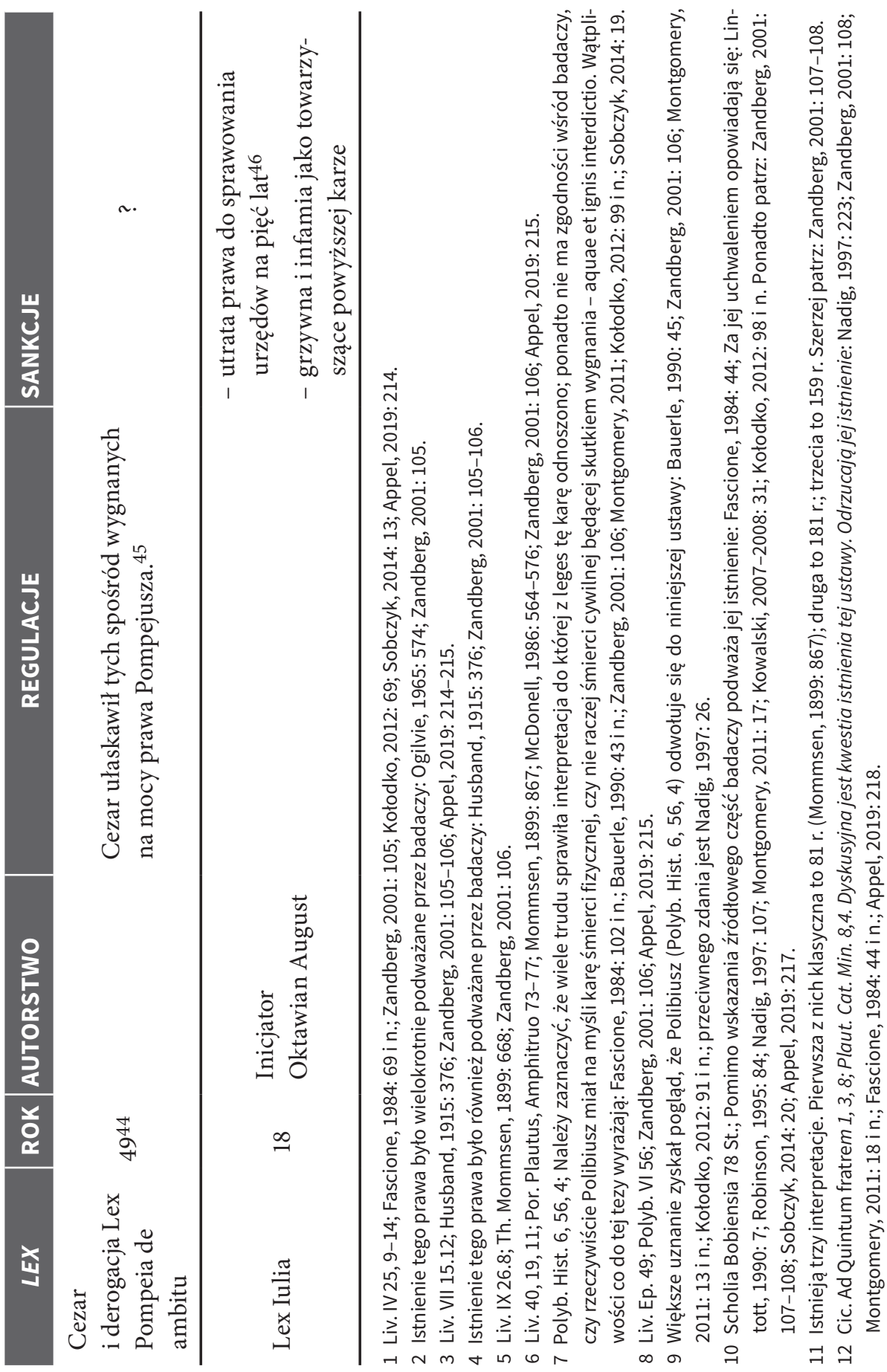




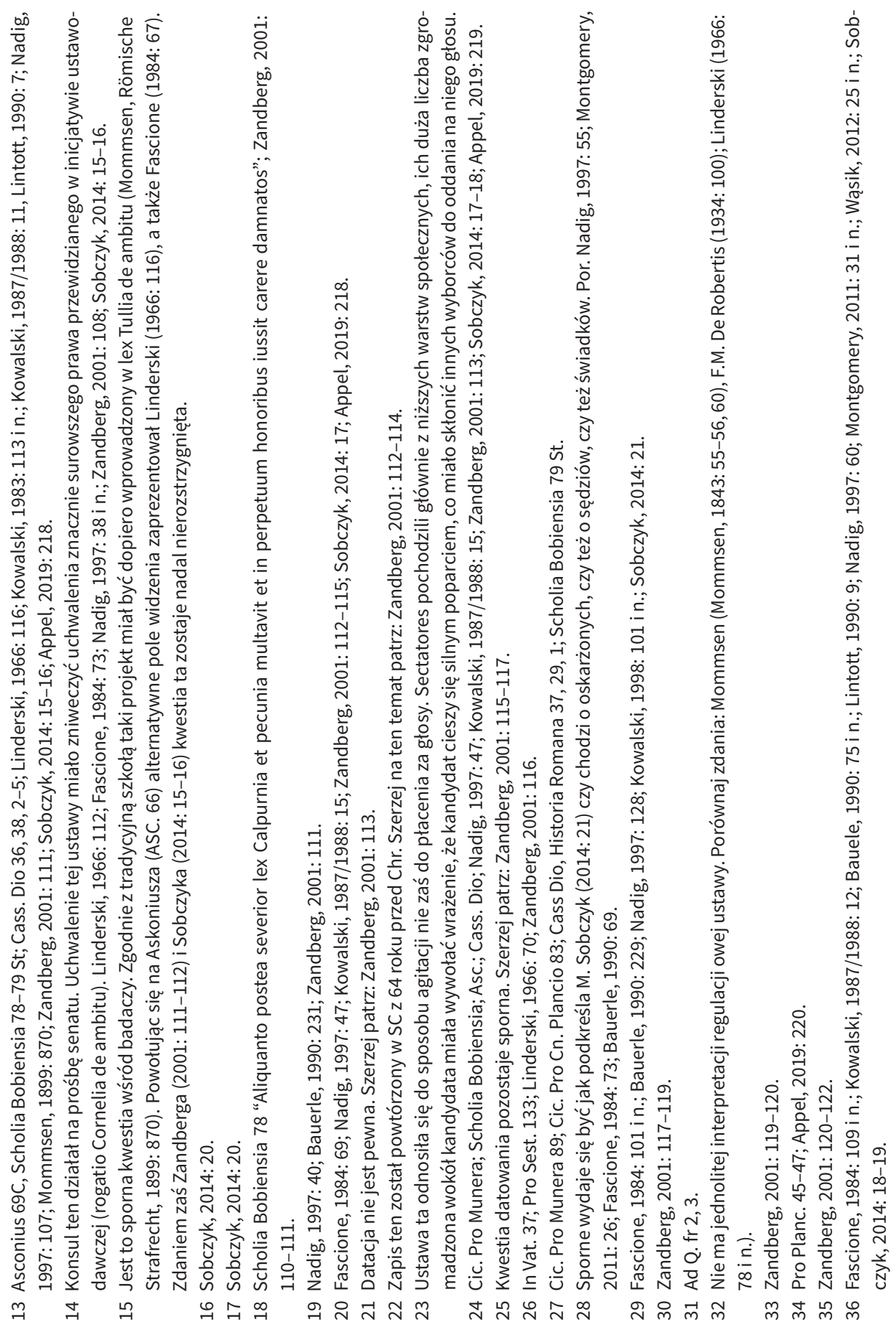




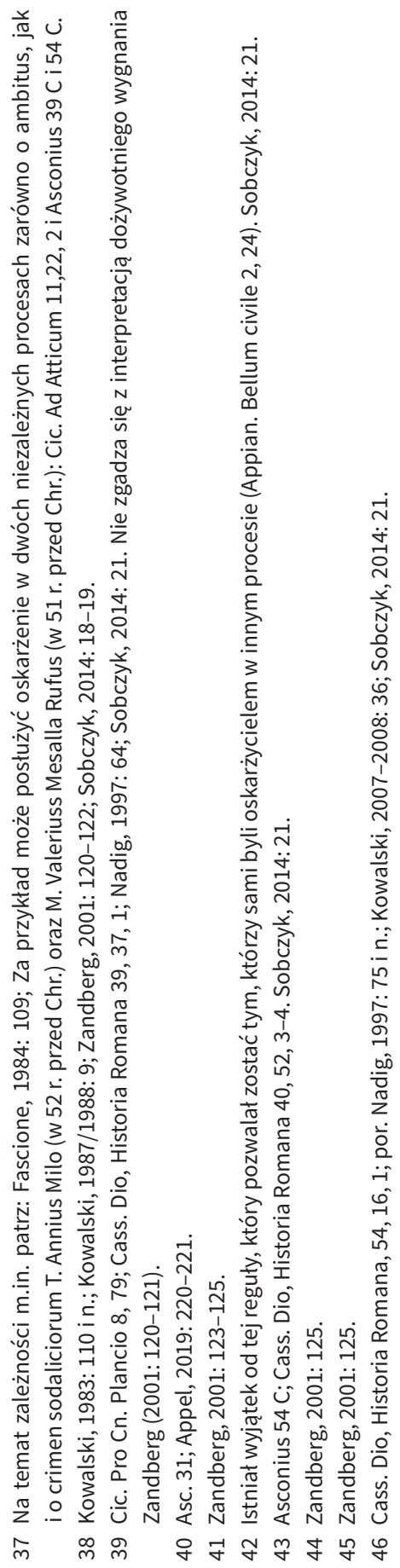




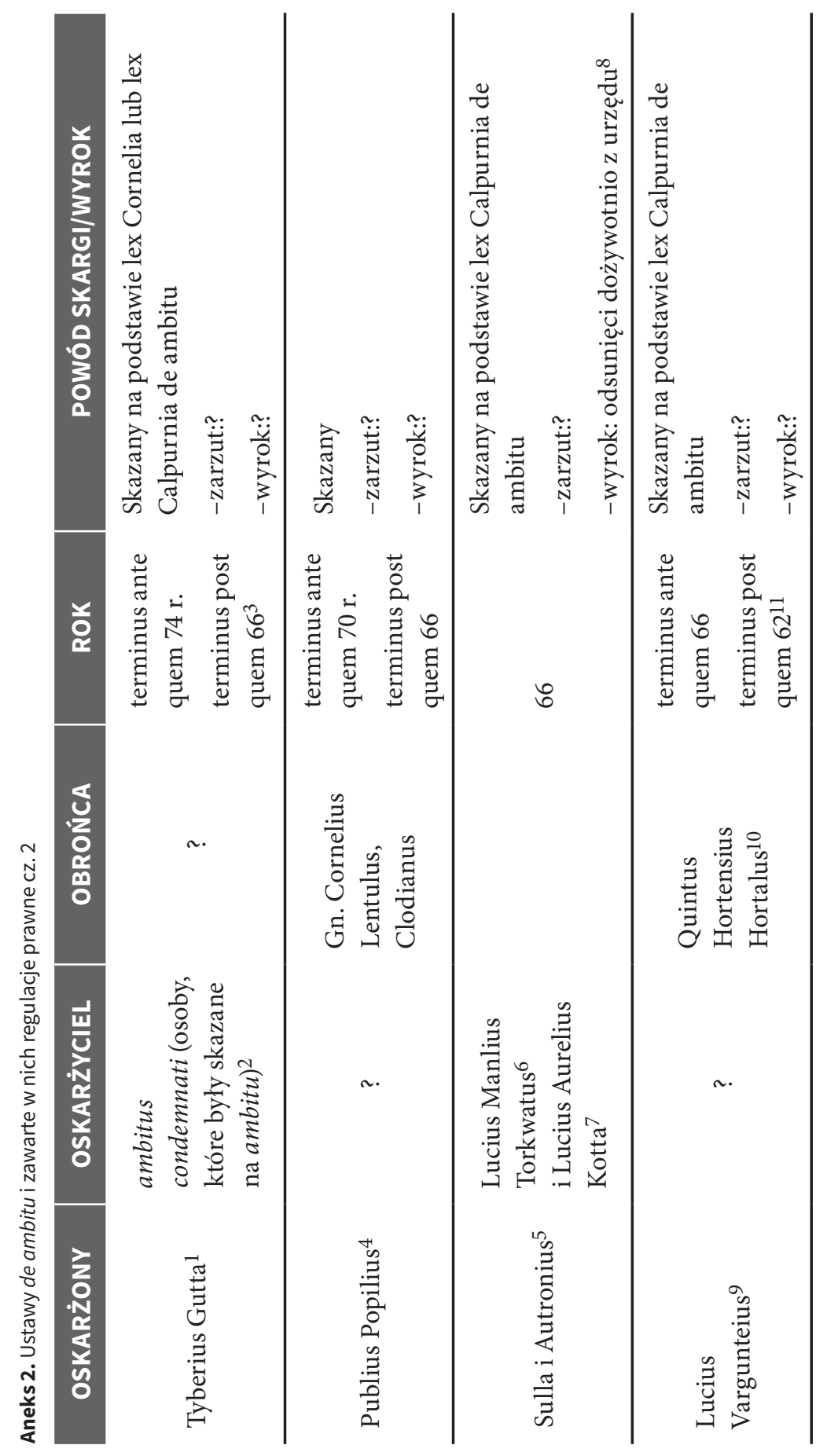

Analiza crimen ambitus w świetle hiszpańskich leges... 


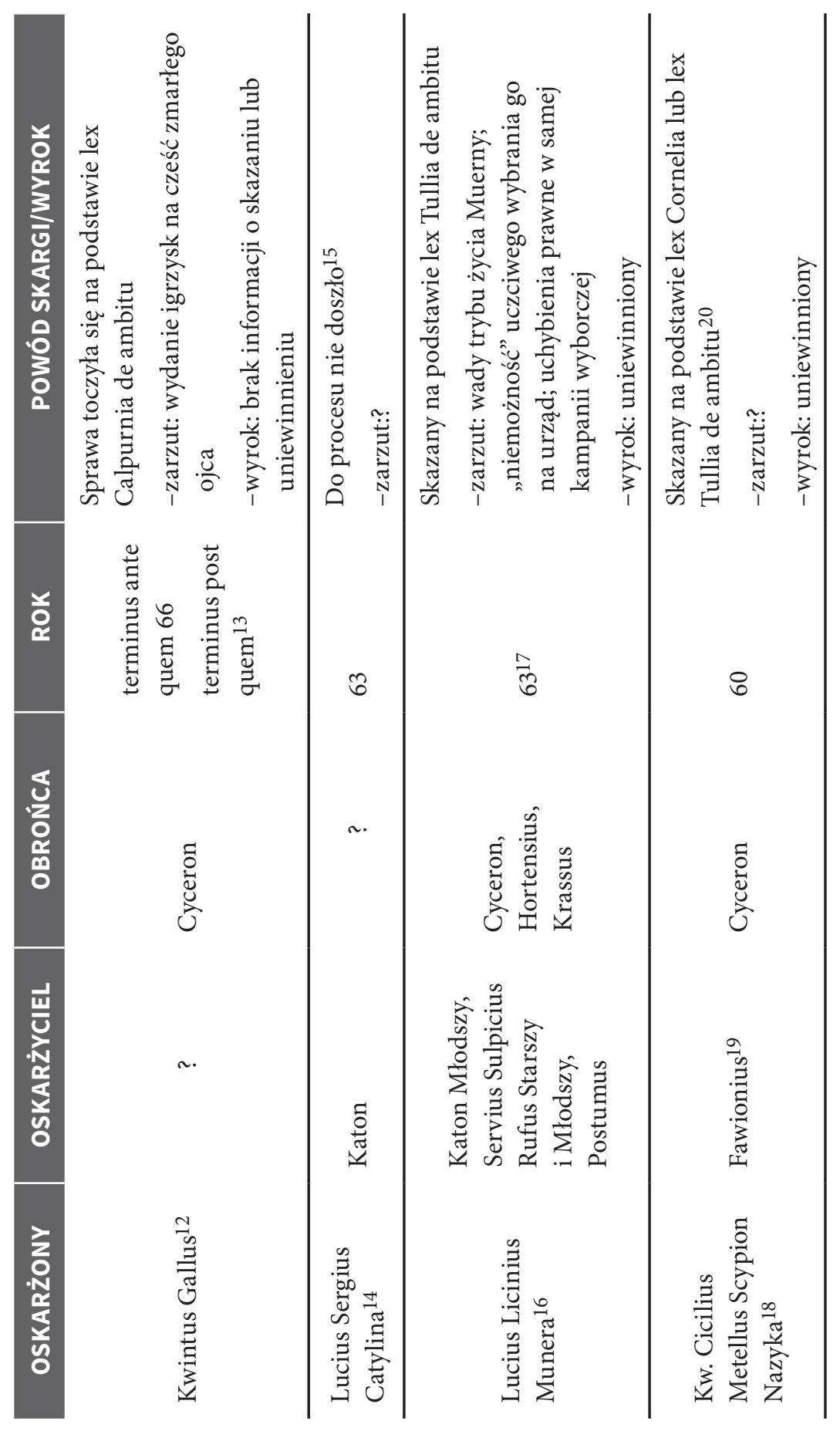




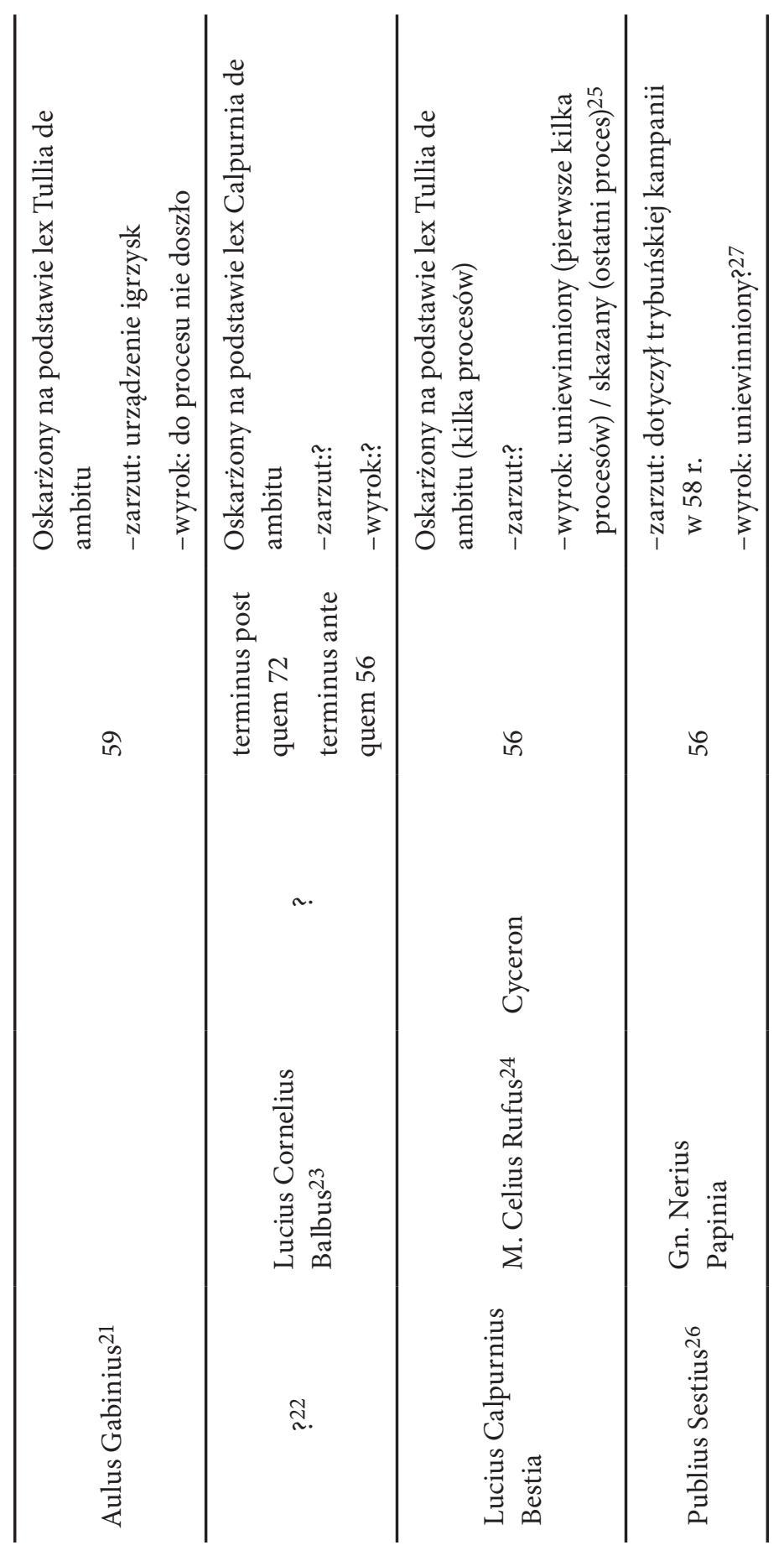




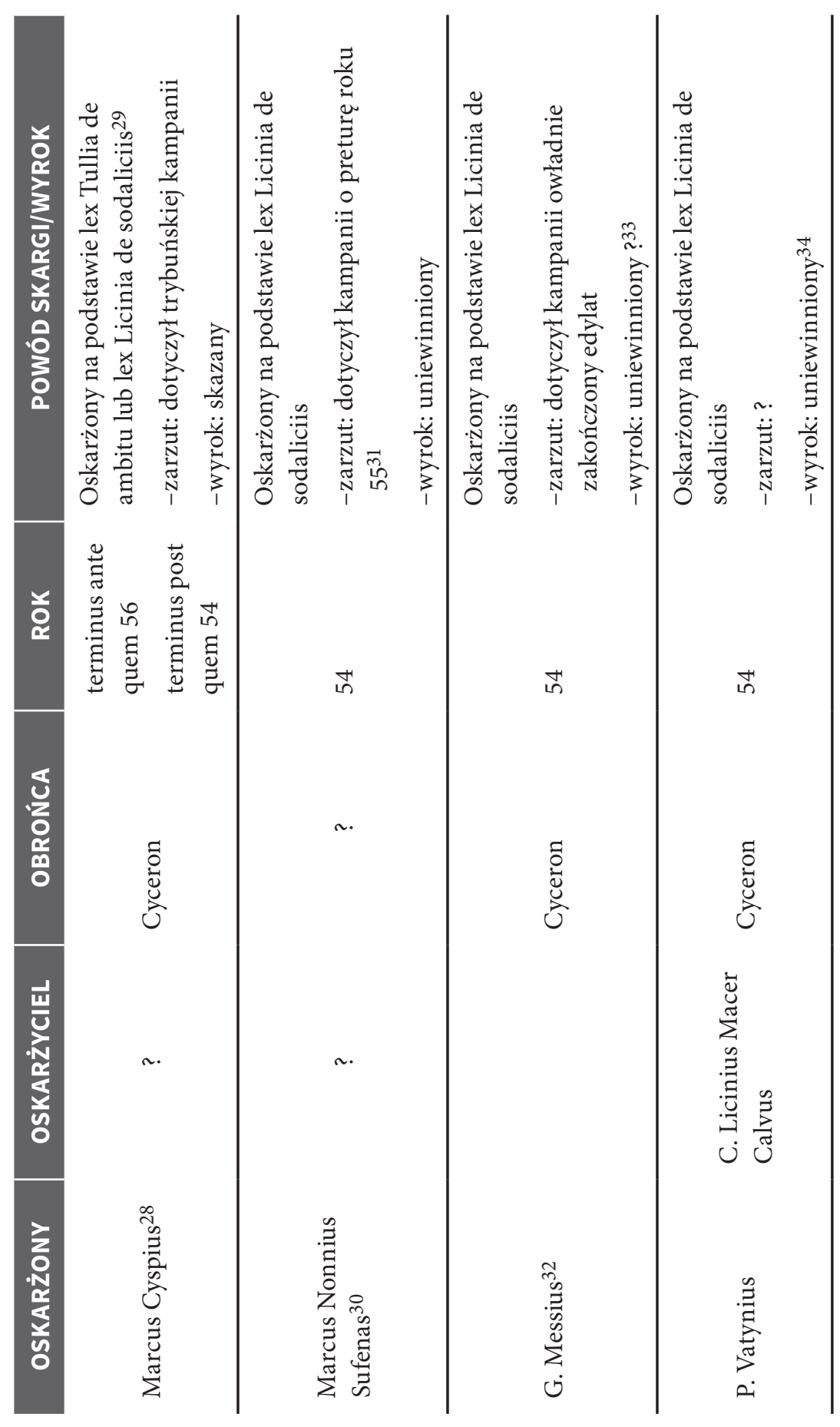




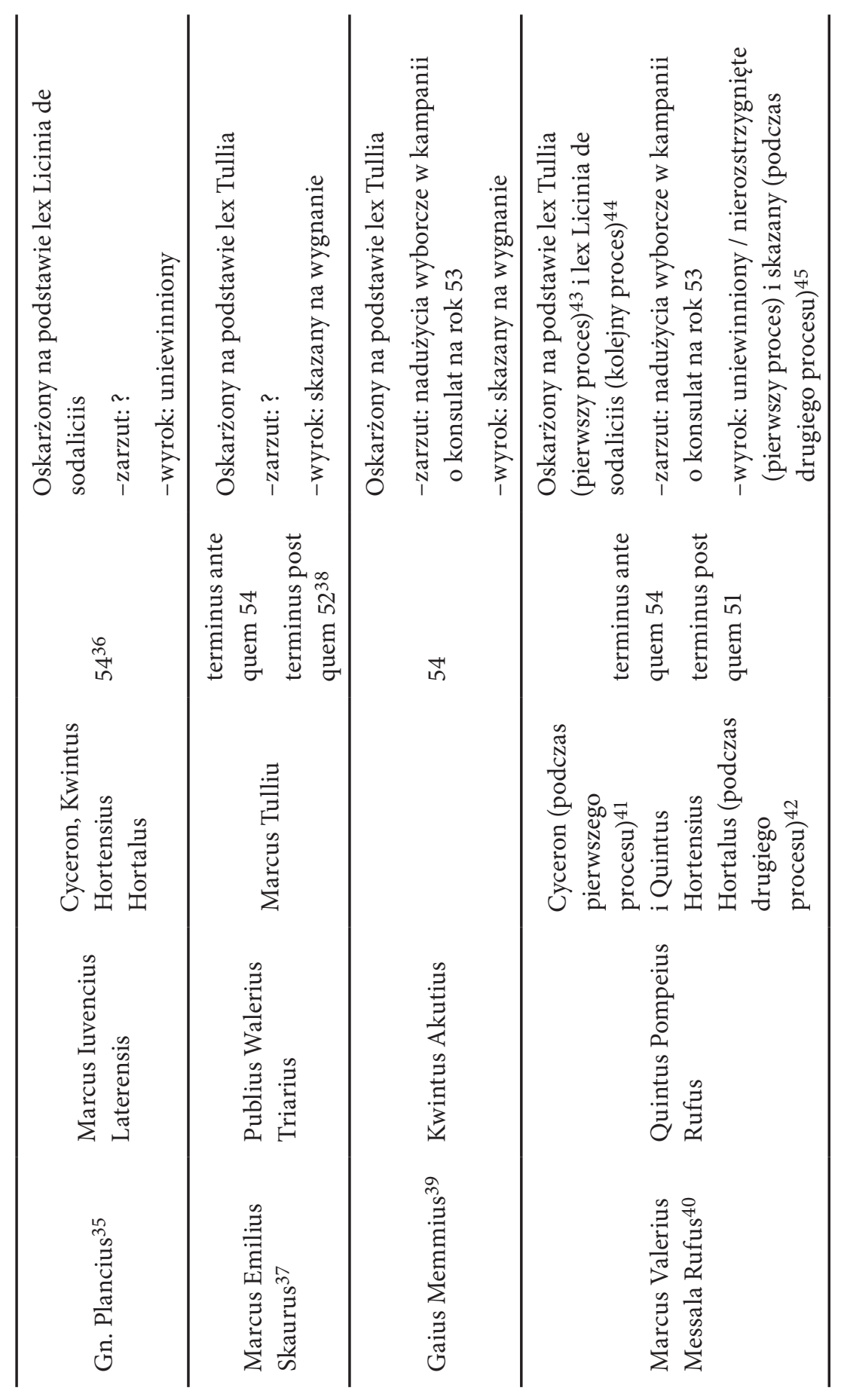




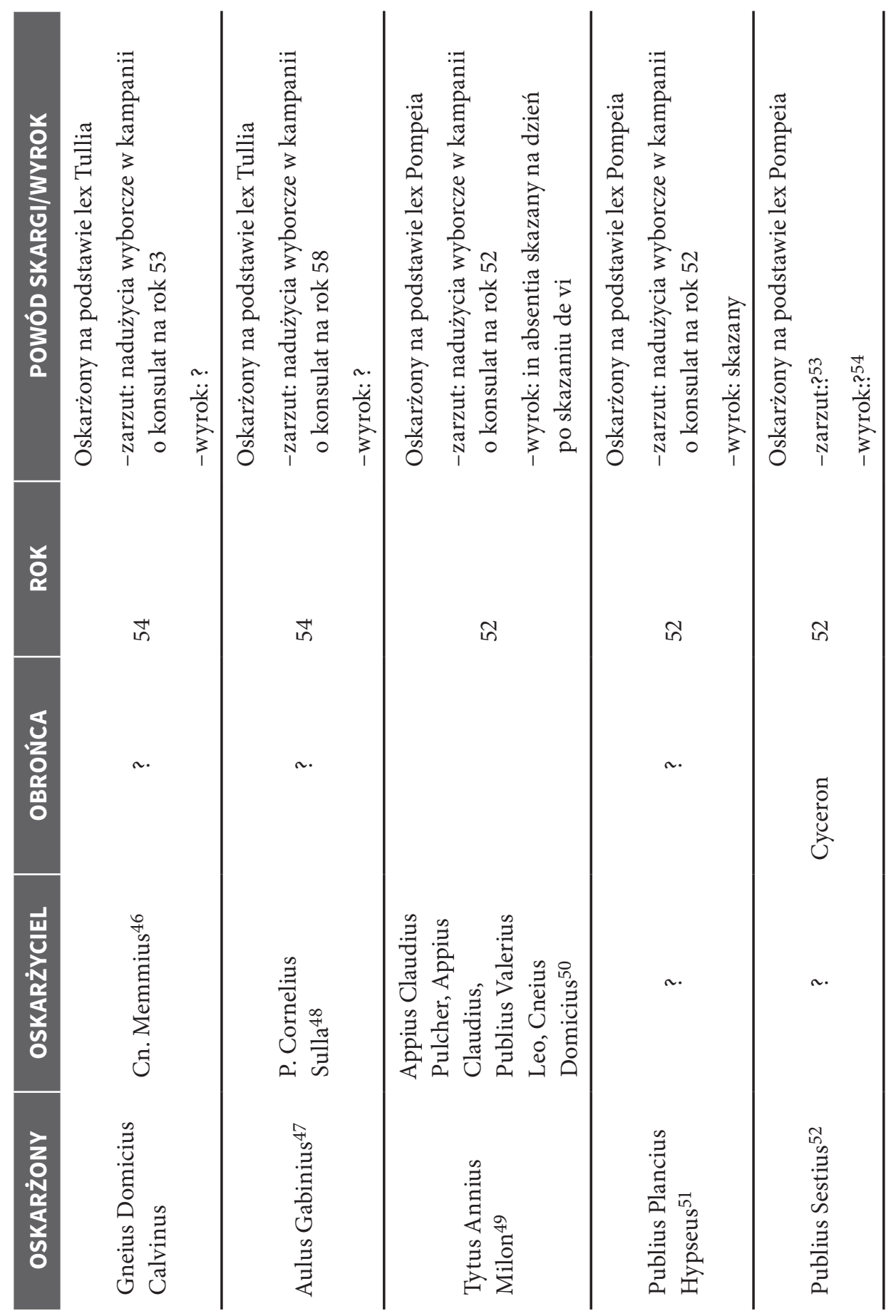




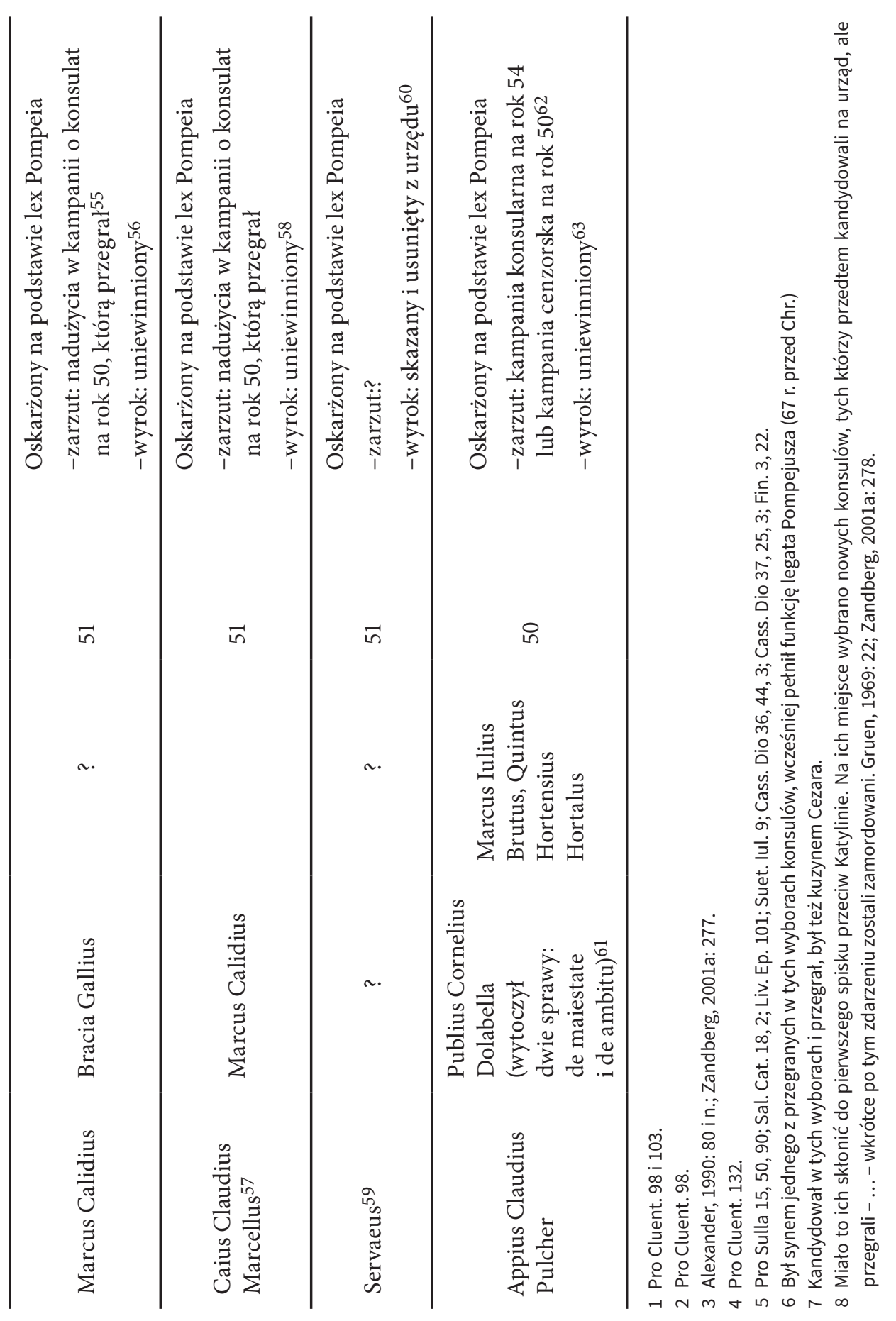




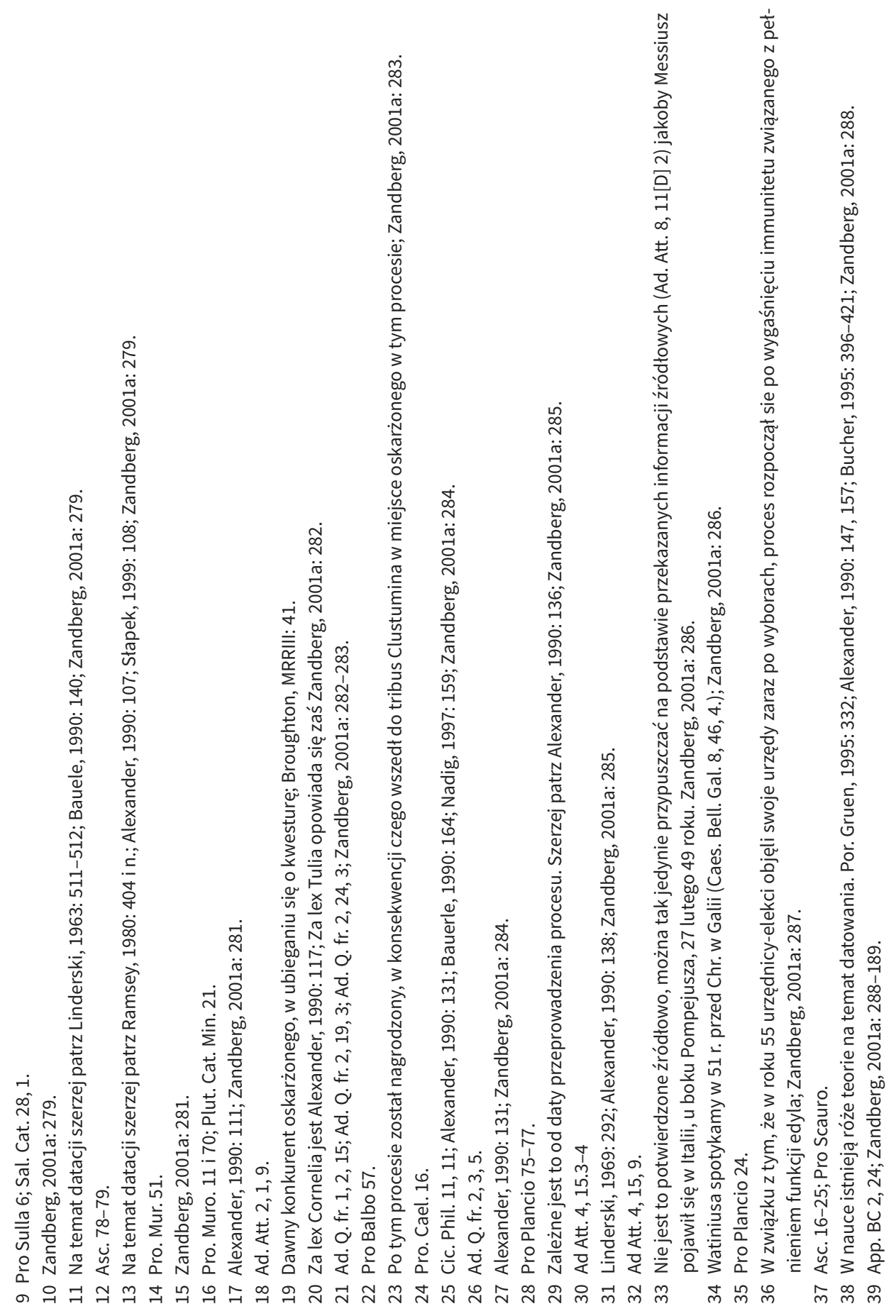




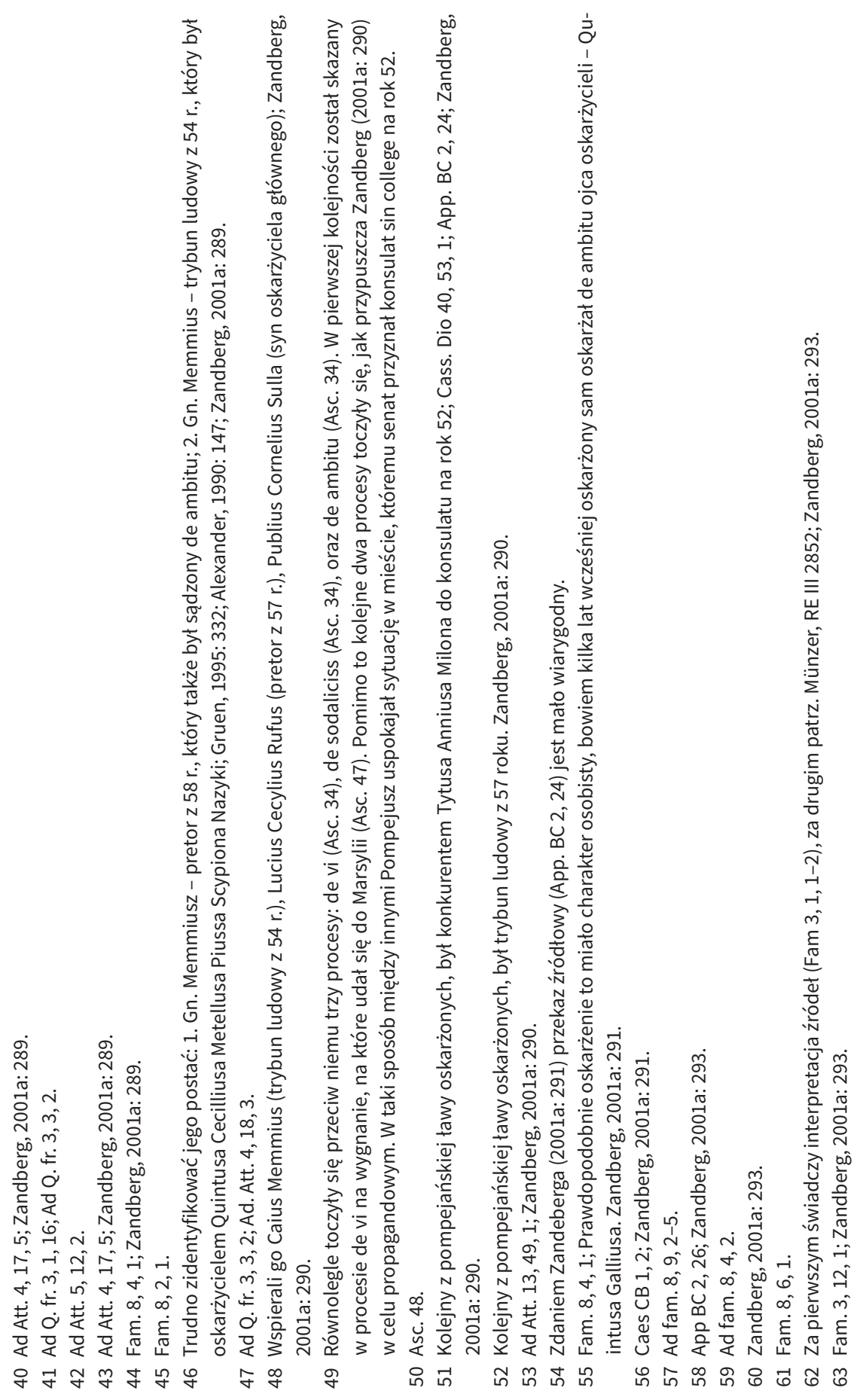




\section{Bibliografia}

Albertini, E. (1923): Les divisons administrative de l'Espagneromaine. Paris.

Alexander, M.C. (1990): Trials in the Lata Romana Republic, 149 BC to 50 BC. Toronto.

Appel, H. (2019): Ite in suffragium. O wyborach $w$ republikańskim Rzymie, Toruń.

Bauerle, E.A. (1990): Procuring and election. Ambitus in the Roman republic 432-49 B.C. Michigan.

Bucher, G.S. (1995): Appian BC II, 24 and the Trial de ambitu of Marcus Aemilius Scaurus, „Historia” 44: 396-421.

De Robertis, F.M. (1934): Il diritto associative romano. Bari.

Fascione, L. (1984): Crimen e quaestio ambitus nell'età republican. Milano.

Frỳdyk, M. (2010): Gli intrygi elettorai a Roma - crimen ambitus, „Studia Prawnoustrojowe” 12: 57-60.

Gruen, E.S. (1969): Notes on First Catilianarian Conspiracy, „Classical Philology" 64: 20-24.

Gruen, E.S. (1995): Last generation of the Roman Republic. Berkely.

Hall, U. (1964): Voting procedure in Roman Assemblies. „Historia” 13: 267-306.

Husband, R.W. (1915): The Law of Poetelius on Corrupt Practices at Elections, „CJ” 10: 376-385.

Jurewicz, A.R. (2012): Komentarz do leges sumptuariae wymienionych $w$ Gell. 2.24, w: P. Kołodko: Ustawodawstwo rzymskie w sprawach karnych: od ustawy XII tablic do dyktatury Sulli. Białystok.

Kowalski, H. (1983): Organizacja przekupstw wyborczych w Rzymie w okresie schyłku republiki. „Acta Universitatis Wratislaviensis, Antiquitas” IX.Wrocław: 107-117.

Kowalski, H. (1987/1988): Przekupstwa wyborcze w Rzymie w okresie schyłku republiki. „Rocznik Lubelski” 29/30: 7-16.

Kowalski, H. (1998): Praemia legis $w$ rzymskim ustawodawstiw de ambitu a I w. p.n.e., „Res historica” 5. Lublin: 101-113.

Kowalski, H. (2007-2008): Die Wahlbestechungen in kaiserzeitlichen Rom. „Pomoerium” 6:29-45. 
Linderski, J. (1963): Cicero and Sallust on Vargunteius. „Historia” 12: 511-512.

Linderski, J. (1966): Rzymskie zgromadzenia wyborcze od Sulli do Cezara. Wrocław-Warszawa-Kraków.

Lintott, A. (1990): Electoral Bribery in Roman Republic. „JRS” 80: $1-16$.

Litewski, W. (2003): Rzymski proces karny. Kraków.

McDonell, M. (1986): Ambitus and Plautus Amphitruo 65-81. „AJP” 107: 564-576.

Mommsen, Th. (1843): De collegiis et sodaliciis Romanorum. Kiliae.

Mommsen, Th. (1899): Römische Strafrecht. Leipzig.

Montgomery, D. (2011): Ambitus: Electoral Corruption and Aristocratic Competition and in the Age of Cicero, w: A. Jurewicz, R. Sajkowski, B. Sitek, J. Szczerbowski, A. Świętoń (red.), Rzymskie prawo publiczne. Wybrane zagadnienia. Olsztyn: 165-170.

Nadig, P. (1997): Ardet ambitus. Untersuchungen zum Phänomen der Wahlbestechungen in der römischen Republik. Frankfurt am Main.

Ogilvie, R.R. (1965): Commentary on Livy 1-5. Oxford.

Perelli, L. (1994): La coruzzione politica nell'antica Roma. Tangentimalversazioni malcostume illeciti raccomandazioni. Milano.

Ramsey, J.T. (1980): A Reconstrucione of Q. Gallius Trial for Ambitus: „One Less Reason for Doubting the Authenticity of the Commentariolum Petitionis”. „Historia” 29: 401-441.

Robinson, O.F. (1995): The Criman Law of Ancient Rome. Duckworth.

Rominkiewicz. J. (2016): O rzymskich ustawach ograniczajacych wydatki na organizację uczt. (Makrobiusz. „Saturnalia” 3,17), „Studia historycznoprawne”: 29-55.

Schuller, W. (2000): Ambitus. Einige neue Gesichtspunkte. „Hyperboreus" 6: 349-361.

Sitek, B. (2008): Lex Coloniae Genetivae Iuliae Sue Ursonensis i Lex Irnitiana. Ustawy municypalne antycznego Rzymu. Tekst, tłumaczenie i komentarz. Poznań.

Sitek, B. (2010): Convivium, cena i donum minus w antycznym Rzymie a współczesne dylematy korupcji wyborczej (crimen ambitus). „Studia Prawnoustrojowe” 11:5-15. 
Sitek, B. (2011): Autonomie lokalne - municypia, w: A. Jurewicz, R. Sajkowski, B. Sitek, J. Szczerbowski, A. Świętoń (red.), Rzymskie prawo publiczne. Wybrane zagadnienia. Olsztyn.

Słapek, D. (1999): Gladiatorzy i polityka. Igrzyska w okresie późnej Republiki Rzymskiej. Warszawa.

Sobczyk, M. (2014): Przestępstwo korupcji wyborczej w republikańskim Rzymie. „Czasopismo Prawno-Historyczne” LXVI, z. 2: 11-30.

Staveley, E.S. (1972): Greek and Roman voting and elections. London.

Taylor, L.R. (1968): Party politicis in the age of Caesar. Berkeley.

Twarowska-Antczak, E. (2012): Flawijskie leges municipales, w: L. Mrozewicz (red.), Studia Flaviana II. Poznań: 171-183.

Twarowska-Antczak, E. (2018): Od lex Iulia municipalis do flawijskich leges municipales. Rozwój rzymskiej administracji municypalne jod Juliusza Cezara do Domicjana. Warszawa.

Twarowska-Antczak, E. (2019): Parvo fames constat, magno fastidium. Rzymskie ustawy ograniczajace przepych biesiad w kontekście społeczno-kulturowym, w: W. Ślusarczyk, D. Gawenda-Kempczyńska, R. Wilczyński (red.), Pokarm i Napój. Studia nad Kultura i Rolą Żywienia. Sytość I głód. Lublin: 119-129.

Wallinga, T. (1994): Ambitus in the Roman Republic, „Revue Internationale des Droits de l'Antiquite" 41. 1994: 411-442.

Wąsik, D. (2012): Przestępstwa przeciwko wyborom i referendum. Olsztyn.

Wołodkiewicz, W. (2007): „Okręcenie” wyborców - czyli crimien ambitus w prawie rzymskim. „Palestra” 11-12: 120-124.

Zandberg, A. (2001): Leges de ambitu u schyłku republiki rzymskiej, „Meander” 56: 103-126.

Zandberg, A. (2001a): Leges de ambitu. Rzymskie ustawodawstwo wyborcze u schyłku republiki (II). „Meander” 56: 277-294. 